\title{
ECONOMIC PROFITABILITY OF PARTICLEBOARDS PRODUCTION WITH A DIVERSIFIED RAW MATERIAL STRUCTURE
}

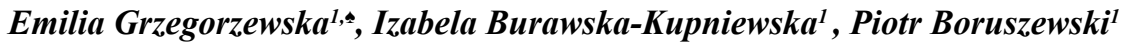

\begin{abstract}
To achieve sustainable development, coherence of three key elements is necessary: economic growth, social inclusion and environmental protection. They are interconnected and all are extremely important for achieving the well-being of individuals and entire societies. One of the key drivers of sustainable economic growth is the furniture industry, which is related to the maximum optimization of production cost while maintaining the high quality of the offered products. However, the expected material deficit may contribute to a significant weakening of growth dynamics. One of the possible solutions to this problem is harvesting timber from plantations of fast-growing trees that could supplement the increasing deficit of wood raw material. The research aimed to determine the cost-effectiveness of particleboard technology modification involving the change in the structure of raw material by introducing wood from fast-growing tree plantations. The research included an estimation of the unit cost of $1 \mathrm{~m}^{3}$ particleboard manufactured in the series production process. The analysis was carried out on the example of one of the leading particleboard suppliers for the Polish furniture industry and consisted in comparing the cost of production of particleboards based on wood from fast-growing tree plantations with the cost of particleboards, which are commonly available on the market. Three variants of the diversified raw material structure were taken into account: $100 \%$ share (1), $50 \%$ share (2) and $25 \%$ share (3) of raw material from fast-growing tree plantations. The time range of the studies was adopted for the years 2014-2020. The research indicates that the introduction of wood from fast-growing tree plantations into the production of particleboards enables the production of material and energy cost savings at the level of $6 \%$ ( ${ }^{\text {rd }}$ variant) to even $17 \%$ ( $1^{\text {st }}$ variant). Variant 1 of material structure can lead to cost reduction at the level of US\$ 13,0 million (in case of particleboards production capacity $570000 \mathrm{~m}^{3}$ ).
\end{abstract}

Keywords: Fast-growing tree plantations, material unit cost, particleboards, production costs reduction, wood based panels.

\section{INTRODUCTION}

Research on alternative raw material resources in wood-based panel technology is stimulating the development of the furniture industry (Khalil et al. 2010, Nicewicz et al. 2012, Gatani et al. 2013, Varanda et al. 2013). Along with the development of the furniture sector, there is a clear increase in the demand for woodbased panels (particleboards and fiberboards). Over the last 20 years, the Polish furniture industry developed dynamically, mainly due to pro-export initiatives. The Polish furniture branch sells $90 \%$ of its production abroad (Grzegorzewska and Stasiak-Betlejewska 2014) and has the highest trade volume of any manufacturing industry.

It should be noted that the value of the sold production of the furniture industry annually increases by

\footnotetext{
${ }^{1}$ Warsaw University of Life Sciences - SGGW, Institute of Wood Sciences and Furniture, Department of Technology and Entrepreneurship in Wood Industry, Warsaw, Poland. 
several percent (Grzegorzewska and Wieckowska 2017, Augustyniak and Minska-Struzik 2018). Therefore, it is highly important to optimize the level of production in the wood industry, covering the demand for furniture production. Stimulating the growth of furniture production should be associated with the development of new products and the elimination of difficulties in access to lignocellulosic raw materials (Boruszewski et al. 2016, Boruszewski et al. 2017, Mirski et al. 2017, Padzil et al. 2018). Unfortunately, the problem of wood deficit has been affecting the wood industry and furniture production for many years, because wood is the basic raw material used in the production process in these industries. Due to the growing demand for wood from a lot of sectors, in 2015 the annual shortage of raw wood for wood-based composites industry in Poland reached the level of around $(7,7-11,4)$ million $\mathrm{m}^{3}$. Wood consumption in the energy sector, with the dynamic development of the wood industry (including wood-based composites industry), can cause the European wood deficit to reach from 230 million $\mathrm{m}^{3}$ to even 500 million $^{3}$ in 2020 (Ratajczak 2013). This situation applies not only to Poland but also to other countries strongly focusing on the development of wood-based industries as the basic production raw material.

Contemporary research trends concern, among others, wood harvested from genetically modified trees (Flachowsky et al. 2009, Brunner et al. 2007, Strauss et al. 2004, Bradshaw and Strauss 2001). This creates the possibility to obtain raw material with chemical, physical and mechanical properties desired and useful for the industry such as low lignin content, a high degree of cellulose polymerization, increased resistance to biocorrosion and others (Dalton et al. 2011, Voelker et al. 2011, Park et al. 2004, James et al. 1998). The use of wood obtained from genetically modified trees seems to be (especially in Europe) a far-off future due to the insufficient cognitive aspect, ethical considerations and the lack of appropriate legal regulations (Gamborg and Sandoe 2010, Muhs 2010, Lang 2004, Strauss et al. 2000).

Insufficient at the current stage, knowledge in the field of genetically modified wood (especially in the utilitarian aspect) creates the necessity to develop new research directions in terms of diversification of the raw material base for the wood-based panels industry. The experience of foresters within the scope of cultivation of fast-growing trees can be extremely beneficial. The advantages of wood raw material from fast-growing tree plantations result not only from its high productivity but also from the possibility of access to a highly concentrated and preferably distributed material base. Based on research conducted for the last 50 years, it has been established that the most useful plantation species for the wood-based panels industry is poplar and larch (Johansson 2013, Zamora et al. 2013). The appropriability of these species results from the large width of the annual ring (thus a high share of earlywood followed by a lower density of wood in comparison to typical forest crops), therefore splitting into wood chips is much easier.

Classical forestry has a long tradition, but additional options and strategies to harvest enough wood to meet the still-increasing demand are needed. Wood plantations with fast-growing woody species and very short rotation periods are one way to solve this problem (Bredemeier et al. 2015). In the world, intensive work is carried out on harvesting timber from plantations of fast-growing trees that could supplement the increasing deficit of wood raw material (Przybysz et al. 2018, Boruszewski et al. 2017, Boruszewski et al. 2016, Zajaczkowski 2006).

A potential area for fast-growing tree plantations depends on the available agricultural land with unfavourable conditions for food production, climate conditions, and water supply (Szostak et al. 2013). The global increase in the area of fast-growing high-yield plantations has reached 3 million hectares, which is a small share of total forest area (Del Lungo et al. 2006), since $30 \%$ of the land on the Earth is covered by forests and only $5 \%$ of that area are plantations (Przybysz et al. 2018). Those fast-growing tree plantations can supply 800 $\mathrm{M}$ tons of lignocellulosic biomass (Carle and Holmgren 2008). There are 363 plantations crops of fast-growing trees in Poland, which are located within 13 out of 17 State Forests Regional Directorates. According to data from the Central Statistical Office of Poland (2014), the area of plantations of fast-growing trees exceeds 143 thou. ha, of which plantations on arable lands cover an area of approximately 8000 ha, and in forests more than 135000 ha. Presently, fast-growing tree plantations serve primarily experimental purposes (Szostak et al. 2013).

According to data from Central Statistical Office of Poland (2010), with only $5 \%$ use of sown area and 5 $\%$ use of forest lands as well as boscage (wooded land and bushy land), it is possible to obtain approximately $1 \mathrm{M}$ ha of land for fast-growing tree plantations. In case of planting $50 \%$ of these lands with larch and $50 \%$ with poplar, and if $50 \%$ capacity of the plantation is assumed, it will be possible to obtain nearly $10 \mathrm{M} \mathrm{m}^{3}$ of wood per year.

The use of wood from fast-growing tree plantations is highly efficient, may reduce the cost-intensity of 
technological processes in terms of raw material prices and processing. Also, lower energy input needed to crumble raw material characterized by lower density and lignin content in comparison to wood from typical forest crops is very important from an economic point of view (Przybysz et al. 2018). The use of a new type of raw material in the wood-based composites industry (especially particleboards technology) requires absolute verification of economic profitability.

\section{MATERIAL AND METHODS}

The aim of the research was to determine the cost-effectiveness of particleboard technology modification involving the change in the structure of raw material as a result of the introduction of wood from fast-growing tree plantations. These analyzes consisted in comparing the cost production of particleboards based on wood from fast-growing tree plantations with the cost of particleboards which are commonly available on the market. The research included an estimation of the unit cost of $1 \mathrm{~m}^{3}$ particleboards manufacturing in the series production process. The analysis was carried out on the example of one of the leading particleboards suppliers for the Polish furniture industry. The basic source of research material was data obtained from the prospectus, financial statements and reports on the activities of the Management Board of Company X and an analytical report on the company prepared by brokerage house BDM S.A. The time range of the studies was adopted for the years 2014-2020, whereas for the last 3 years the results have a prognostic dimension and were prepared based on some assumptions. The basic activities of Company $\mathrm{X}$ are the production of particleboards, laminated boards and other wood and wood-based composites, production of other wooden products and coating, paper and cardboard impregnation. The company offers a wide range of boards of varying quality and a wide spectrum of prices, from standard products to more expensive and more complex products with higher added value. These products go not only to the domestic market but also to more than 20 countries. Company X realizes the majority of its sales revenues from relatively large industrial customers, among which an important group belongs to the furniture industry.

Research procedure consisted of several steps. First, the annual volume of production and sales of particleboards was determined. Next, using the information on the average sale price of $1 \mathrm{~m}^{3}$ of particleboards, the level of sales revenues of this product in the analyzed company was determined.

Based on the available financial data and information obtained from the prospectus, Management Board reports on the company's operations and an analytical report prepared by BDM S.A, cost of product sold was calculated. Cost of product sold is the expense incurred by a company to sell a product. It includes raw and packing material costs and production costs until the payment for the product is received. In other words, it is the cost of producing or buying a product, including the cost of selling it and indirect costs closely related to product sales. Based on the cost of product sold and the volume of sales of individual product ranges, the unit cost of sales per $1 \mathrm{~m}^{3}$ of particleboards was estimated.

Then the structure of the cost of product sold was estimated. The following categories of costs were distinguished:

- costs of raw materials,

- $\quad$ costs of energy,

- personnel costs,

- depreciation,

- $\quad$ other costs, i.e. cost of sales and general management costs, but those related to the sale of products.

In the next stage, the unit cost of materials (including traditional wood raw material) and energy, referred to analyzed Company X were determined. Then, based on the price difference between materials, typical raw wood and wood derived from fast-growing tree plantations, as well as lower energy consumption needed for the process (a result of the specific anatomy and chemical composition of wood from fast-growing trees), a comparison of their unit cost was made.

Economic analyzes were carried out for three variants of the raw material structure. Due to the low proba- 
bility of using $100 \%$ share of wood from fast-growing tree plantations $\left(1^{\text {st }}\right.$ variant of economic analysis $)$ in the particleboards' production, $50 \%\left(2^{\text {nd }}\right.$ variant $)$ and $25 \%$ ( $3^{\text {rd }}$ variant $)$ were also taken into account.

\section{RESULTS AND DISCUSSION}

Research material shows that Company X can produce $600000 \mathrm{~m}^{3}$ of particleboards in one year. The average manufacturing capacity utilization was set at $95 \%$. This means that the annual particleboards production can easily reach the level of $570000 \mathrm{~m}^{3}$.

For the years 2018-2020 the same capacity utilization, thus productivity and production volume was assumed. Due to the significant value of capacity (95\%), a further increase in production volume would be possible when new investments were made. However, to allow comparison, a decision was made to accept the data presented in the analytical report of the BDM S.A.

As shown in Table 1, Company X sold $632000 \mathrm{~m}^{3}$ of wood-based panels in 2014, with the sales volume of particleboards at the level of $475000 \mathrm{~m}^{3}$. Earnings forecasts indicate that in 2020 Company X will sell 435000 $\mathrm{m}^{3}$ of particleboards. This means a decrease in comparison to the base year (2014) by approx. $8 \%$. The change in the sales structure results, among others, from the expected increase in sales (by $18 \%$ ) of Melamine Faced Chipboard (MFC).

In 2014, the average selling price of particleboards reached the level of US\$166,8 per $1 \mathrm{~m}^{3}$. By 2020 , this price should increase slightly to US\$ 173,8 . It should be noted, however, that there was a decrease of US\$ 1,6 and US\$ 2,2 in 2015-2016 from the 2014 price. Additionally, it is worth noting that, in the case of particleboards, stable growth is expected year-to-year starting from 2017.

In the analyzed company, the cash revenue on sales in 2014 reached US\$ 407,1 million. The prognosis assumes that, by 2020 , the value of sales revenues will increase to US $\$ 453,4$ million, which means an increase of US\$ 46,3 million (11\%) since 2014. In 2018-2020, sales revenue is expected to increase by an average of $1 \%$ to $3 \%$.

It should be emphasized that apart from particleboards, the analyzed company also generates revenues from the sale of MFC boards. At the end of the period under review, the revenues from the sale of this assortment are expected to be at a level of US\$ 170 million.

The expected reduction in production volume of particleboards will also lead to a decrease in revenues from the sale of this material. It is forecasted that a reduction in sales revenue of particleboards can be at a level of around $14 \%$.

Table 1: Selected data on the sale of particleboards in 2014-2020.

\begin{tabular}{|l|c|r|r|r|r|r|r|r|}
\hline \multicolumn{1}{|c|}{ Sales data: } & Unit & 2014 & 2015 & 2016 & 2017 & $2018^{*}$ & $2019 *$ & $2020^{*}$ \\
\hline $\begin{array}{l}\text { Sales volume } \\
\text { (x 1000), incl.: }\end{array}$ & $\mathrm{m}^{3}$ & 632 & 618 & 611 & 612 & 605 & 590 & 585 \\
\hline $\begin{array}{l}\text { Particleboards } \\
\text { (x 1000) }\end{array}$ & $\mathrm{m}^{3}$ & 475 & 491 & 484 & 470 & 455, & 440 & 435 \\
\hline $\begin{array}{l}\text { Av. price of } \\
\text { particleboards }\end{array}$ & US\$ / $\mathrm{m}^{3}$ & 166,8 & 165,2 & 164,6 & 168,8 & 170,0 & 171,8 & 173,8 \\
\hline $\begin{array}{l}\text { Sales revenues, } \\
\text { incl.: }\end{array}$ & $\begin{array}{c}\text { millions } \\
\text { US\$ }\end{array}$ & 407,1 & 418,5 & 395,6 & 427,1 & 442,3 & 450,4 & 453,4 \\
\hline Particleboards & $\begin{array}{c}\text { millions } \\
\text { US } \$\end{array}$ & 79,2 & 81,1 & 79,7 & 79,3 & 77,3 & 75,5 & 75,8 \\
\hline
\end{tabular}

Source: own study based on Analytical Report of BDM S.A. 
Based on the analysis of the data obtained from the prospectus, financial statements and reports of the Management Board, as well as an analytical report prepared by BDM S.A., it was assumed that the cost of product sold constitutes about $80 \%$ of total sales revenue. Table 2 shows that, in 2014, the cost of product sold was US\$ 325,6 million. The prognosis is that by 2020 it will be by $11,4 \%$ higher (US\$ 362,8 million). In the case of particleboard production, the cost of product sold in 2014 was at the level of US\$ 63,4 million. However, due to the expected reduction in the production of particleboards, it is forecasted that in 2020 the cost of product sold will reach US\$ 60,5 million, which is about 4,6 \% less than the value recorded in 2014.

Based on the cost of product sold and sales volumes of individual product ranges, the unit cost of sales per $1 \mathrm{~m}^{3}$ of the board was estimated. The analyzes show that in 2014 the unit cost of sales of particleboards was at US\$ 133,5 per $1 \mathrm{~m}^{3}$. In the following two years, the value was lower by US\$1,3 and 1,8 however, from 2017 , a slight increase is forecasted (about $1 \%$ annually). In 2020, the cost of sales will be at the level of US\$139,2 per $1 \mathrm{~m}^{3}$ of particleboards.

Table 2: Cost of product sold (particleboards) in 2014-2020.

\begin{tabular}{|l|c|r|r|r|r|r|r|r|}
\hline Sales data & Unit & 2014 & 2015 & \multicolumn{1}{|c|}{2016} & \multicolumn{1}{|c|}{2017} & $2018^{*}$ & $2019 *$ & $2020^{*}$ \\
\hline $\begin{array}{l}\text { Cost of product } \\
\text { sold, incl.: }\end{array}$ & $\begin{array}{c}\text { millions } \\
\text { US\$ }\end{array}$ & 325,6 & 334,8 & 316,5 & 341,7 & 353,8 & 360,3 & 362,8 \\
\hline Particleboards & $\begin{array}{c}\text { millions } \\
\text { US\$ }\end{array}$ & 63,4 & 64,9 & 63,8 & 63,4 & 61,9 & 60,4 & 60,5 \\
\hline $\begin{array}{l}\text { Unit cost of } \\
\text { sales } \\
\text { particleboards }\end{array}$ & $\begin{array}{c}\text { US\$ / } \\
\mathrm{m}^{3}\end{array}$ & 133,5 & 132,2 & 131,7 & 133,8 & 136,0 & 137,4 & 139,2 \\
\hline \multicolumn{8}{|c|}{ *Prognosis. }
\end{tabular}

Source: own study based on Analytical Report of BDM S.A. and reports of Management Board.

The analysis of the cost of product sold structure shows that the cost of raw materials has the largest share in the cost of sales (Figure 1). They represent nearly $2 / 3$ of all costs. Further costs incurred by the company are personnel costs $(11 \%)$ and energy costs $(10 \%)$. The costs related to the depreciation of buildings, machines and tools constituted approximately $5 \%$ of the cost of products sold with the costs of sales and general management around $8 \%$.

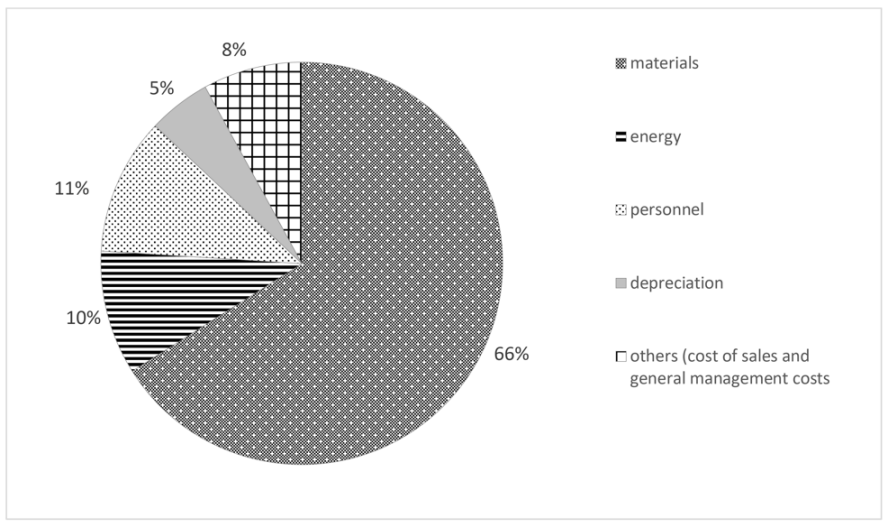

Figure 1: The structure of the cost of product sold in a Company X. Source: own study based on Prospectus Reports of Management Board. 
On the basis of the presented cost of product sold structure, the unit production cost (which does not include costs related to sales and general management) and unit cost of product sold, which includes these indirect costs was estimated. In 2014 the production cost of $1 \mathrm{~m}^{3}$ of particleboards was at the level of US\$ 122,8 (Table 3).

Table 3: Unit production cost and unit cost of product sold of particleboards.

\begin{tabular}{|c|c|c|c|c|c|c|c|c|}
\hline Type of cost & Unit & 2014 & 2015 & 2016 & 2017 & $2018^{*}$ & $2019 *$ & $2020^{*}$ \\
\hline Material & $\mathrm{US} \$ / \mathrm{m}^{3}$ & 88,1 & 87,3 & 86,9 & 88,3 & 89,7 & 90,6 & 91,9 \\
\hline Energy & $\mathrm{USS} / \mathrm{m}^{3}$ & 13,3 & 13,2 & 13,2 & 13,4 & 13,5 & 13,8 & 13,9 \\
\hline Personnel & $\mathrm{US} \$ / \mathrm{m}^{3}$ & 14,7 & 14,5 & 14,4 & 14,8 & 15,0 & 15,1 & 15,3 \\
\hline Depreciation & $\mathrm{US} \$ / \mathrm{m}^{3}$ & 6,7 & 6,6 & 6,6 & 6,7 & 6,8 & 6,8 & 6,9 \\
\hline Unit production cost & $\mathrm{US} \$ / \mathrm{m}^{3}$ & 122,8 & 121,6 & 121,2 & 123,1 & 125,1 & 126,4 & 128,1 \\
\hline $\begin{array}{l}\text { Others (cost of sales } \\
\text { and general } \\
\text { management costs) }\end{array}$ & $\mathrm{US} \$ / \mathrm{m}^{3}$ & 10,7 & 10,5 & 10,5 & 10,7 & 10,9 & 11,0 & 11,1 \\
\hline $\begin{array}{l}\text { Unit cost of product } \\
\text { sold }\end{array}$ & $\mathrm{US} \$ / \mathrm{m}^{3}$ & 133,5 & 132,2 & 131,7 & 133,8 & 136,0 & 137,4 & 139,2 \\
\hline
\end{tabular}

*Prognosis.

Source: own study based on Analytical Report of BDM S.A. and Reports of Management Board.

In the following two years, this cost dropped slightly, by US\$ 1,2 and $1,6 \mathrm{per} \mathrm{m}^{3}$, respectively. The forecast assumes a slight increase in production costs in 2018-2020. The analysis shows also that the unit cost of sales of particleboards may increase by $4,3 \%$ in the reviewed period from US\$ 133,5 to 139,2 per $\mathrm{m}^{3}$.

Among the most important materials and energy used in the production process of particleboards, there can be mentioned: wood raw material, additives (including adhesives), paper and energy. The structure of material costs in the analyzed company is as follows: wood raw material $-37 \%$, additives - $30 \%$, paper - 16 $\%$, energy $13 \%$ and other costs $-4 \%$. On the basis of the material cost structure, the unit cost of materials and energy in Company $\mathrm{X}$ was estimated (Table 4). At the beginning of the period under consideration, the cost of materials and energy was US\$ 101,3 per $\mathrm{m}^{3}$ of particleboards. Specifically, the cost of wood was US\$37,5 per $\mathrm{m}^{3}$, additives (for example paraffin emulsion) US $\$ 30,4$ per $\mathrm{m}^{3}$, paper US $\$ 16,2$ per $\mathrm{m}^{3}$, energy US\$13,2

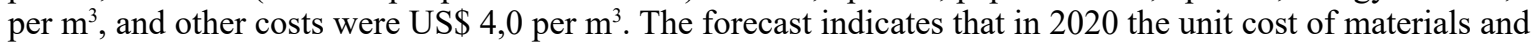
energy will be US\$ 4,6 per $\mathrm{m}^{3}$ higher than in 2014.

Table 4: The unit cost of materials and energy in the production of particleboards.

\begin{tabular}{|l|c|c|c|c|c|c|c|c|}
\hline Type of cost & Unit & 2014 & 2015 & 2016 & 2017 & $2018 *$ & $2019 *$ & $2020^{*}$ \\
\hline $\begin{array}{l}\text { Material and } \\
\text { energy cost, incl.: }\end{array}$ & $\mathrm{USS} / \mathrm{m}^{3}$ & 101,3 & 100,5 & 100,2 & 101,7 & 103,3 & 104,4 & 105,9 \\
\hline Wood & $\mathrm{USS} / \mathrm{m}^{3}$ & 37,5 & 37,2 & 37,1 & 37,6 & 38,3 & 38,7 & 39,2 \\
\hline Additives & $\mathrm{USS} / \mathrm{m}^{3}$ & 30,4 & 30,1 & 30,0 & 30,5 & 31,0 & 31,3 & 31,8 \\
\hline Paper & $\mathrm{USS} / \mathrm{m}^{3}$ & 16,2 & 16,1 & 16,0 & 16,2 & 16,6 & 16,7 & 16,9 \\
\hline Energy & $\mathrm{USS} / \mathrm{m}^{3}$ & 13,2 & 13,1 & 13,0 & 13,2 & 13,4 & 13,5 & 13,8 \\
\hline Others & $\mathrm{USS} / \mathrm{m}^{3}$ & 4,0 & 4,0 & 4,0 & 4,0 & 4,1 & 4,1 & 4,2 \\
\hline
\end{tabular}

Source: own study based on Analytical Report of BDM S.A. and Reports of Management Board. 
Based on the available information, it was estimated that the cost of raw wood material used for the production of $1 \mathrm{~m}^{3}$ of particleboards in 2014 amounted to US\$ 37,5. For the production of $1 \mathrm{~m}^{3}$ of particleboards, approximately $1,4 \mathrm{~m}^{3}$ of wood raw material is consumed. This means that the cost of $1 \mathrm{~m}^{3}$ of timber is at US\$ 26,7. On the other hand, the average price of medium-sized timber in forest districts in 2014 ranged from US\$ 35,1 per $\mathrm{m}^{3}$ of alder to US $\$ 40,7$ per $\mathrm{m}^{3}$ of spruce (pine cost 39,9 US\$ for $1 \mathrm{~m}^{3}$ ) (Grzegorzewska et al. 2016).

It should be emphasized that the share of specific types of wood raw material in particleboards technology is individually selected by producers and often deviates from the assumptions given in the literature on the subject. According to the literature (Boruszewski 2012), the structure of the raw material is as follows: pulpwood (medium-sized wood) - $42 \%$, small wooden elements - $17 \%$, wood chips - $21 \%$, sawdust - $15 \%$, edgings - 4 $\%$, other $1 \%$. However, in economic practice, it is assumed that in the raw material structure:

- $\quad$ share of pulpwood should not be less than $10 \%$,

- $\quad$ share of sawdust should not be greater than $17 \%$,

- $\quad$ share of edgings should not exceed $37 \%$.

Due to the above, the unit cost of materials and energy in the particleboards technology was estimated, taking into account the use of better quality of wood raw material (medium-sized wood and wood chips). The cost of a better-quality raw material, based on information from the analytical report prepared by BDM SA, was assumed to be at US $\$ 48$ per $\mathrm{m}^{3}$. Therefore, in 2014 the cost of materials and energy incurred for the production of particleboards would be US\$ 131,1 per $\mathrm{m}^{3}$ (Table 5). This is due to the increase in wood raw material cost from US\$ 37,5 to US\$ 67,3 .

Price forecasts for better quality wood (and thus the cost of wood raw material) for the following years were estimated based on the dynamics of price changes and dollar exchange rates acquired from BDM S.A.

The difference between production technology based on traditional wood raw material and raw material from fast-growing tree plantations concern mainly the cost of wood and energy. Therefore, the focus was on determining the unit cost of materials and energy. The following assumptions, confirmed by empirical studies on a laboratory scale, were adopted:

- $\quad$ price of $1 \mathrm{~m}^{3}$ of raw material from fast-growing tree plantations - US\$31,9,

- $\quad$ consumption of wood raw material per $1 \mathrm{~m}^{3}$ of particleboards $-1,4 \mathrm{~m}^{3}$,

- reduction of energy use by $15 \%$ in the case of raw material from fast-growing tree plantations in comparison to energy demand in the case of wood cutting processing from typical forest crops (based on unpublished results obtained in industrial tests).

Table 5: The unit cost of materials and energy in the production of particleboards taking into account the use of better quality of wood raw material.

\begin{tabular}{|l|c|r|r|r|r|r|r|r|}
\hline Type of cost & Unit & 2014 & 2015 & 2016 & 2017 & 2018 & $2019 *$ & $2020 *$ \\
\hline $\begin{array}{l}\text { Costs of } \\
\text { materials and } \\
\text { energy, incl.: }\end{array}$ & $\mathrm{US} \$ / \mathrm{m}^{3}$ & 131,1 & 127,8 & 122,9 & 124,1 & 126,3 & 128,2 & 130,4 \\
\hline Wood & $\mathrm{US} \$ / \mathrm{m}^{3}$ & 67,3 & 64,6 & 59,9 & 60,1 & 61,3 & 62,4 & 63,8 \\
\hline Additives & $\mathrm{US} \$ \mathrm{~m}^{3}$ & 30,4 & 30,1 & 30,0 & 30,5 & 31,0 & 31,3 & 31,8 \\
\hline Paper & $\mathrm{US} \$ / \mathrm{m}^{3}$ & 16,2 & 16,1 & 16,0 & 16,2 & 16,6 & 16,7 & 16,9 \\
\hline Energy & $\mathrm{US} \$ / \mathrm{m}^{3}$ & 13,2 & 13,1 & 13,0 & 13,2 & 13,4 & 13,5 & 13,8 \\
\hline Others & $\mathrm{US} \$ \mathrm{~m}^{3}$ & 4,0 & 4,0 & 4,0 & 4,0 & 4,1 & 4,1 & 4,3 \\
\hline & \multicolumn{7}{|c}{$*$ Prognosis. }
\end{tabular}

Source: own study based on Analytical Report of BDM S.A. and Reports of Management Board. 
As shown in Table 6, the unit cost of materials and energy in the production of particleboards with a $100 \%$ share of raw material from fast-growing tree plantations in 2014 would be US\$108,3 per $\mathrm{m}^{3}$, being US\$22,8 per $\mathrm{m}^{3}$ lower than with currently-used technology (using traditional material from typical forest crops). This decrease is due to lower unit costs of wood raw material (US\$ 46,4 against US\$ 67,3) and energy consumption (US\$ 11,2 against US\$ 13,2). Replacement of traditional raw material with material from fast-growing tree plantations results in a material and energy saving of $17 \%$.

Due to the fact that the scenario assuming $100 \%$ utilization of material from fast-growing tree plantations in the particleboards process is unlikely in the current technological conditions, the unit cost of materials and energy for the following two variants was analyzed (50\% and $25 \%$ share).

Table 6: The unit cost of materials and energy in the production of particleboards taking into account the use of wood raw material from fast-growing tree plantations.

\begin{tabular}{|c|c|c|c|c|c|c|c|c|}
\hline Type of cost & Unit & 2014 & 2015 & 2016 & 2017 & $2018^{*}$ & $2019 *$ & $2020^{*}$ \\
\hline \multicolumn{9}{|c|}{$1^{\text {st }}$ variant - the share of raw material from fast-growing tree plantations $-100 \%$} \\
\hline $\begin{array}{l}\text { Cost of material } \\
\text { and energy, incl.: }\end{array}$ & US\$ $/ \mathrm{m}^{3}$ & 108,3 & 105,9 & 102,4 & 103,5 & 105,3 & 106,9 & 108,5 \\
\hline Wood & $\mathrm{US} \$ / \mathrm{m}^{3}$ & 46,4 & 44,5 & 41,3 & 41,4 & 42,3 & 43,1 & 44,0 \\
\hline Energy & $\mathrm{US} \$ / \mathrm{m}^{3}$ & 11,2 & 11,1 & 11,1 & 11,2 & 11,4 & 11,5 & 11,6 \\
\hline \multicolumn{9}{|c|}{$2^{\text {nd }}$ variant - the share of raw material from fast-growing tree plantations $-50 \%$} \\
\hline $\begin{array}{l}\text { Cost of material } \\
\text { and energy, incl.: }\end{array}$ & US\$ $/ \mathrm{m}^{3}$ & 118,8 & 115,8 & 109,8 & 110,9 & 112,9 & 114,6 & 116,4 \\
\hline Wood & $\mathrm{US} \$ / \mathrm{m}^{3}$ & 56,8 & 54,5 & 48,7 & 48,8 & 49,8 & 50,8 & 51,8 \\
\hline Energy & $\mathrm{US} \$ / \mathrm{m}^{3}$ & 11,2 & 11,1 & 11,1 & 11,2 & 11,4 & 11,5 & 11,6 \\
\hline \multicolumn{9}{|c|}{$3^{\text {rd }}$ variant - the share of raw material from fast-growing tree plantations $-25 \%$} \\
\hline $\begin{array}{l}\text { Cost of material } \\
\text { and energy, incl.: }\end{array}$ & $\mathrm{US} \$ / \mathrm{m}^{3}$ & 124,0 & 120,9 & 116,3 & 117,5 & 119,6 & 121,4 & 123,4 \\
\hline Wood & $\mathrm{US} \$ / \mathrm{m}^{3}$ & 62,1 & 59,5 & 55,2 & 55,4 & 56,5 & 57,6 & 58,7 \\
\hline Energy & $\mathrm{US} \$ / \mathrm{m}^{3}$ & 11,2 & 11,1 & 11,1 & 11,2 & 11,4 & 11,5 & 11,6 \\
\hline
\end{tabular}

Source: own study based on Analytical Report of BDM S.A. and Reports of Management Board.

When using a raw material structure in which the share of traditional raw materials and from fast-growing tree plantations is equal ( $50 \%$ share of each), the cost of materials and energy would be US\$118,8 per $\mathrm{m}^{3}$, which is $9 \%$ less than using only traditional wood raw material.

If the share of wood from fast-growing tree plantations in raw material structure is $25 \%$, the unit cost of materials and energy would be at the level of US\$ 124,0 per $\mathrm{m}^{3}$. It means that the cost of materials and energy per $1 \mathrm{~m}^{3}$ would be almost $6 \%$ less expensive than in typical production technology.

According to the analyzes, taking into account the production capacity of Company $\mathrm{X}$ at the level of $570000 \mathrm{~m}^{3}$ of particleboards, application of a diversified raw material structure would reduce costs in the base year by US\$13,0 million respectively for the first variant (100\% share), US\$ 7,0 million for the second variant (50\% share), and US\$ 4,0 million for the third option ( $25 \%$ share of raw material from fast-growing tree plantations). Presented forecasts for 2020 show that assumed variants of raw material structure including plantation raw material would contribute to a reduction in the level of raw material and energy costs by US\$ 12,1 million (1st variant), US\$ 7,9 million (2nd variant) and US\$3,9 million (3rd variant). 


\section{CONCLUSIONS}

The research indicates that the introduction of wood raw material from fast-growing tree plantations into the production of particleboards enables the production of material and energy cost savings at the level of 6 $\%$ ( $3^{\text {rd }}$ variant) to even $17 \%$ ( $1^{\text {st }}$ variant $)$. The study showed that the unit cost of materials and energy in case

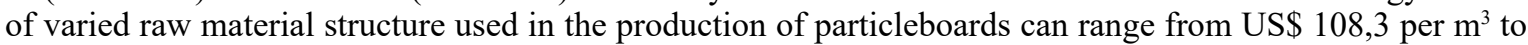
US\$124,0 per $\mathrm{m}^{3}$.

Changes in the current raw material structure in particleboards technology, through the use of new raw materials (wood from fast-growing tree plantations), will positively affect the continued growth dynamics of wood-based boards production. It should be noted, however, that the possibility of further sector development is related to the maximum optimization of production costs while maintaining the high quality of the offered products. Consumption of materials and energy (mainly wood) has a significant share in production costs.

Therefore, the idea of implementation of wood raw material from fast-growing tree plantations in particleboards technology results from the increasing difficulties in access to traditional wood raw material. Preservation a further dynamic growth in production in the wood industry forces the use of alternative material sources.

\section{ACKNOWLEDGMENTS}

The authors are grateful for the support of the National Centre for Research and Development, Grant. No. LIDER/002/406/L-4/NCBR/2013. Article submitted: 5.05.2019.

\section{REFERENCES}

Augustyniak, D.; Minska-Struzik, E. 2018. The competitiveness of polish furniture exports. Drewno 61(202): 21-38. http://dx.doi.org/10.12841/wood.1644-3985.D15.04.

Boruszewski, P. 2012. Raw materials for the wood based composites industry. In Raw Materials and Particleboards - a Current Status and Perspectives Part I: 5-20. Boruszewski, P.; Mamiński, M.; Ružinská, E. (Eds.). WULS-SGGW Press: Warsaw, Poland. https://www.epnp.pl/ebook/A05357_raw_materials_and_particleboard

Boruszewski, P.; Borysiuk, P.; Mamiński, M.; Czechowska, J. 2016. Mat compression measurements during low - density particleboard manufacturing. BioResources 11(3): 6909-6919. http://dx.doi.org/10.15376/ biores.11.3.6909-6919

Boruszewski, P.; Jankowska, A.; Kurowska, A. 2017. Comparison of the structure of juvenile and mature wood of Larix decidua Mill. from fast-growing plantations in Poland. BioResources 12(1): 1813-1825. http://dx.doi.org/10.15376/biores.12.1.1813-1825

Bradshaw Jr., H.D.; Strauss, S.H. 2001. Breeding strategies for the 21st Century: domestication of poplar. In Poplar Culture in North America. Part B, Chapter 14: 383-394. Dickmann, D.I.; Isebrands, J.G.; Eckenwalder, J.H.; Richardson, J. (Eds.). National Research Council Press. Ottawa, Canada. http://people.forestry.oregonstate.edu/steve-strauss/sites/devel-d7.forestry.oregonstate.edu.steve-strauss/files/Bradshaw_2002_Poplar_Culture_in_North_America.pdf

Bredemeier, M.; Busch, G.; Hartmann, L.; Jansen, M.; Richter, F.; Lamersdorf, N.P. 2015. Fast growing plantations for wood production-integration of ecological effects and economic perspectives. Front 
Bioeng Biotech 3: 72. http://dx.doi.org/10.3389/fbioe.2015.00072.

Brunner, A.M.; Li, J.; Difazio, S.P.; Shevchenko, O.; Montgomery, B.E.; Mohamed, R.; Wei, H.; Ma, C.; Elias, A.A.; Van Wormer, K.; Strauss, S.H. 2007. Genetic containment of forest plantations. Tree Genet Genomes 3(2): 75-100. http://dx.doi.org/10.1007/s11295-006-0067-8

Carle, J.B.; Holmgren, L.P.B. 2008. Wood from planted forests: Global outlook to 2030, Planted Forests: Uses, Impacts and Sustainability. J. Evans (ed.), CAB International and Food and Agriculture Organization of the United Nations, Rome, Italy. http://dx.doi.org/10.1079/9781845935641.0047

Central Statistical Office. 2010. Powszechny Spis Rolny 2010 - Obszary wiejskie. (Rural Areas in Poland - National Agricultural Census 2010). http://stat.gov.pl/obszary-tematyczne/rolnictwo-lesnictwo/psr-2010/ powszechny-spis-rolny-2010-obszary-wiejskie,1,1.html

Central Statistical Office. 2014. Rocznik Statystyczny Rolnictwa 2014. (Statistical Yearbook of Agriculture 2014). http://stat.gov.pl/obszary-tematyczne/roczniki-statystyczne/roczniki-statystyczne/rocznik-statystyczny-rolnictwa-2014,6,8.html

Dalton, D.A.; Ma, C.; Shrestha, S.; Kitin, P.; Strauss, S.H. 2011. Trade-offs between biomass growth and inducible biosynthesis of polyhydroxybutyrate in transgenic poplar. Plant Biotechnol J 9(7): 759-767. https://dx.doi.org/10.1111/j.1467-7652.2010.00585.x

Del Lungo, A.; Ball, J.; Carle, J. 2006. Global planted forests thematic study: results and analysis. (Planted Forests and Trees Working Paper FP/38E), Food and Agricultural Organization, Rome, Italy. http://www.fao.org/forestry/12139-03441d093f070ea7d7c4e3ec3f306507.pdf

Flachowsky, H.; Hanke, H.; Peil, M.V.; Strauss, S.H.; Fladung, M. 2009. A review on transgenic approaches to accelerate breeding of woody plants. Plant Breeding 128(3): 217-226. http://dx.doi.org/10.1111/j.1439-0523.2008.01591.x

Gamborg, C.; Sandoe, P. 2010. Ethical considerations regarding genetically modified trees. In Forests and genetically modified trees: 163-175. El-Kassaby, Y.A.; Prado, J.A. (Eds.). The Food and Agriculture Organization of the United Nations (FAO): Rome, Italy. http://www.fao.org/3/i1699e/i1699e.pdf

Gatani, M.P.; Fiorelli, J.; Medina, J.C.; Arguelo, R.; Ruiz, A.; Nascimento, M.F.; Savastano Jr., H. 2013. Technical production viability and properties of particleboard made with peanut husks. Materia 18(2): 1286-1293. http://dx.doi.org/10.1590/S1517-70762013000200004

Grzegorzewska, E.; Więckowska, M. 2017. The economic profitability of Polish furniture market against a background of the industry sector. In Proceedings of 10th International Scientific Conference WoodEMA. Czech University of Life Sciences Press. Prague, Czech Republic. pp. 218-224. http://www.woodema.org/ proceedings/WoodEMA_2017_Proceedings.pdf

Grzegorzewska, E.; Boruszewski, P.; Jenczyk-Tolloczko, I. 2016. Trends in middle-sized wood supply on the Polish market in 2011-2015. Annals of Warsaw University of Life Sciences - SGGW. Forestry and Wood Technology 94: 246-250. https://sgw0.bg.sggw.pl/exlibris/aleph/a22_1/apache_media/ID7F6NEEGBPEAM92TTXHVL3677JXDI.pdf

Grzegorzewska, E.; Stasiak-Betlejewska, R. 2014. The influence of global crisis on financial liquidity and changes in corporate debt of the furniture sector in Poland. Drvna Ind 65(4): 315-322. http://dx.doi.org/10.5552/drind.2014.1342

James, R.R.; Difazio, S.P.; Brunner, A.M.; Strauss, S.H. $1998 . \quad$ Environmental effects of genetically engineered woody biomass crops. Biomass Bioenerg 14(4): 403-414. http://doi.org/10.1016/s0961-9534(97)10077-0

Johansson, T. 2013. Biomass equations for hybrid larch growing on farmland. Biomass Bioenerg 49: $152-$ 159. https://doi.org/10.1016/j.biombioe.2012.12.020. 
Khalil, H.A.; Firdaus, M.N.; Jawaid, M.; Anis, M.; Ridzuan, R.; Mohamed, A.R. 2010. Development and material properties of new hybrid medium density fibreboard from empty fruit bunch and rubberwood. Mater Design 31(9): 4229-4236. http://dx.doi.org/10.1016/j.matdes.2010.04.014

Lang, C. 2004. Genetically modified trees: the ultimate threat to forests. World Rainforest Movement Press. Montevideo, Uruguay. http://wrm.org.uy/wp-content/uploads/2013/04/Genetically_Modified-Trees_ The_Ultimate_Threat_to_Forests.pdf

Mirski, R.; Boruszewski, P.; Trociński, A.; Dziurka, D. 2017. The possibility to use long fibres from fast growing hemp (Cannabis sativa L.) for the production of boards for the building and furniture industry. BioResources 12(2): 3521-3529. http://dx.doi.org/10.15376/biores.12.2.3521-3529

Muhs, H.J. 2010. Regulation for genetically modified forest reproductive material moving in international trade. In Forests and genetically modified trees: 163-175. El-Kassaby, Y.A.; Prado, J.A. (Eds.). The Food and Agriculture Organization of the United Nations (FAO). Rome, Italy. http://www.fao.org/3/i1699e/i1699e.pdf

Nicewicz, D.; Boruszewski, P.; Klimczewski, M. 2012. Influence of addition of wood from containers and pallets and selected technological parameters on the properties of MDF. Wood Res-Slovakia 57(2): 309316. http://www.woodresearch.sk/wr/201202/13.pdf

Padzil, F.N.M.; Ariffin, H.; Zakaria, S.; Boruszewski, P.; Krajewski, K.; Mamiński, M. 2018. Effect of Poplar cultivar "Hybrid 275" fiber impregnation with DMDHEU on the properties of high density fiberboards. Bioresources 13(4): 7470-7480. http://dx.doi.org/10.15376/biores.13.4.7470-7480

Park, Y.W.; Baba, K.; Furuta, Y.; Iida, I.; Sameshima, K.; Arai, M.; Hayashi, T. 2004. Enhancement of growth and cellulose accumulation by overexpression of xyloglucanase in poplar. FEBS Letters 564(1-2): 183-187. http://dx.doi.org/10.1016/s0014-5793(04)00346-1

Przybysz, K.; Małachowska, E.; Martyniak, D.; Boruszewski, P.; Iłowska, J.; Kalinowska, H.; Przybysz, P. 2018. Yield of pulp, dimensional properties of fibers, and properties of paper produced from fast Growing trees and grasses. BioResources 13(1): 1372-1387. http://dx.doi.org/10.15376/biores.13.1.1372-1387

Ratajczak, E. 2013. Sektor leśno-drzewny $w$ zielonej gospodarce. ITD Press. Poznań, Poland. https://www.itd.poznan.pl/pl/produkt/sektor-lesno-drzewny-w-zielonej-gospodarce

Strauss, S.H.; Brunner, A.M.; Busov, V.B.; Ma, C.; Meilan, R. 2004. Ten lessons from 15 years of transgenic Populus research. Forestry 77(5): 455-465. http://dx.doi.org/10.1093/forestry/77.5.455

Strauss, S.H.; Raffa, K.F.; List, P.C. 2000. Ethics and genetically engineered Plantations. J Forest 98(7): 47-48. http://people.forestry.oregonstate.edu/steve-strauss/sites/devel-d7.forestry.oregonstate.edu.stevestrauss/files/Strauss_2000_J_For.pdf

Szostak, A.; Bidzińska, G.; Ratajczak, E.; Herbeć, M. 2013. Wood biomass from plantations of fast-growing trees as an alternative source of wood raw material in Poland. Drewno 56(190): 85-113. http://dx.doi.org/10.12841/wood.1644-3985.037.07

Varanda, L.D.; Nascimento, M.F.; Christoforo, A.L.; Silva, D.A. L.; Lahr, F.A.R. 2013. Oat hulls as addition to high density panels production. Mat Res 16(6): 1355-1361. http://dx.doi.org/10.1590/S1516-14392013005000131

Voelker, S.L.; Lachenbruch, B.; Meinzer, F.C.; Kitin, P.; Strauss, S.H. 2011. Transgenic poplars with reduced lignin show impaired xylem conductivity, growth efficiency and survival. Plant Cell Environ 34(4): 655-668. http://dx.doi.org/10.1111/j.1365-3040.2010.02270.x

Zajaczkowski, K. 2006. Dobór odmian topól i wierzb do uprawy na plantacjach drzew szybkorosnących. In Elementy genetyki i hodowli selekcyjnej drzew leśnych: 281-301. Sabor, J. (Ed.). Centrum Informacyjne Lasów Państwowych Press: Warsaw, Poland. http://genetyka-lesna.pl/wp-content/uploads/2016/03/Sabor-2006-Elementy-genetyki-i-hodowli-selekcyjnej-drzew-le\%C5\%9Bnych.pdf 
Zamora, D.; Wyatt, G.; Apostol, K.; Tschirner, U. 2013. Biomass yield, energy values, and chemical composition of hybrid poplar in short rotation woody crops production and native perennial grasses in Minnesota, USA. Biomass Bioenerg 49: 222-230. http://dx.doi.org/10.1016/j.biombioe.2012.12.031 